\title{
APT Blanket Detailed Bin Model Based on Initial Plate-Type Design -3D FLOWTRAN-TF Model
}

by

L. L. Hamm

Westinghouse Savannah River Company

Savannah River Site

Aiken, South Carolina 29808

S. Y. Lee

M. A. Shadday

F. G. Smith, III

A document prepared for SENDING TO LANL at , , from - .

DOE Contract No. DE-AC09-96SR18500

This paper was prepared in connection with work done under the above contract number with the U.S. Department of Energy. By acceptance of this paper, the publisher and/or recipient acknowledges the U.S. Government's right to retain a nonexclusive, royalty-free license in and to any copyright covering this paper, along with the right to reproduce and to authorize others to reproduce all or part of the copyrighted paper. 


\section{DISCLAIMER}

Portions of this document may be illegible in electronic image products. Images are produced from the best available original document. 


\section{APT BLANKET DETAILED BIN MODEL BASED ON INITIAL PLATE-TYPE DESIGN}

\section{-3D FLOWTRAN-TF Model}

L. Larry Hamm

Si Young Lee

M. Andy Shadday

Frank G. Smith, III

Westinghouse Savannah River Company

Savannah River Site

Aiken, SC 29808

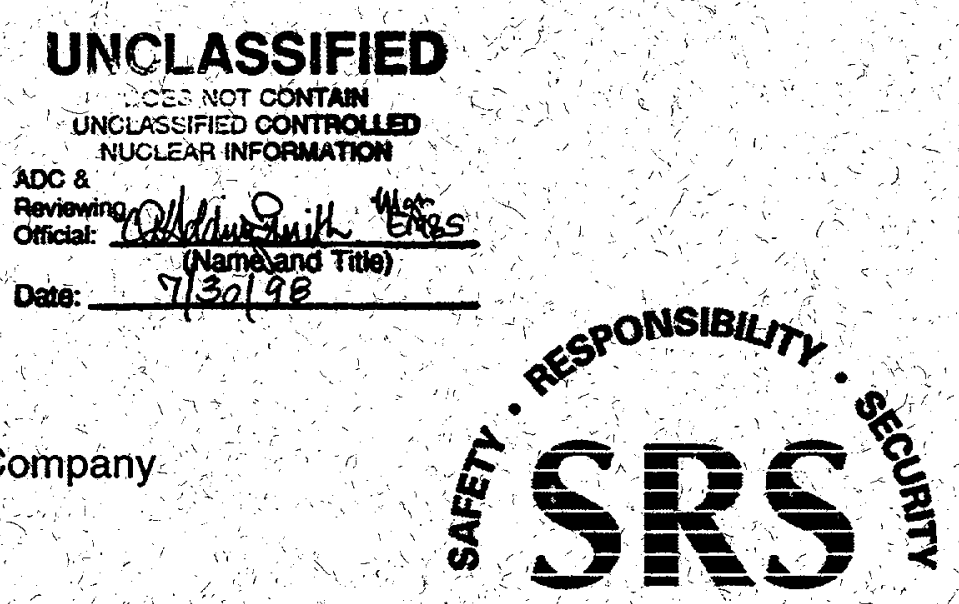




\section{DISCLAIMER}

This report was prepared as an account of work sponsored by an agency of the United States Government. Neither the United States Government nor any agency thereof, nor any of their employees, makes any warranty, express or implied, or assumes any legal liability or responsibility for the accuracy, completeness, or usefulness of any information, apparatus, product, or process disclosed, or represents that its use would not infringe privately owned rights. Reference herein to any specific commercial product, process, or service by trade name, trademark, manufacturer, or otherwise does not necessarily constitute or imply its endorsement, recommendation, or favoring by the United States Government or any agency thereof. The views and opinions of authors expressed herein do not necessarily state or reflect those of the United States Government or any agency thereof.

This report has been reproduced directly from the best available copy.

Available to DOE and DOE contractors from the Office of Scientific and Technical Information, P.O. Box 62, Oak Ridge, TN 37831; prices available from (615) 576-8401.

Available to the public from the National Technical Information Service, U.S. Department of Commerce; 5285 Port Royal Road, Springfield, VA 22161. 
WSRC-TR-98-0055

KEYWORDS:

Accelerator Production of Tritium

Blanket System

Conceptual Design

FLOWTRAN-TF Code

Detailed Bin Model

Safety Analysis

RETENTION - Permanent

\section{APT BLANKET DETAILED BIN MODEL BASED ON INITIAL PLATE-TYPE DESIGN -}

\section{D FLOWTRAN-TF Model}

SAVANNAH RIVER TECHNOLOGY CENTER

L. Larry Hamm

Si Young Lee

M. Andy Shadday

Frank G. Smith, III

Publication Date: July 1998

Westinghouse Savannah River Company

Savannah River Site

Aiken, SC 29808

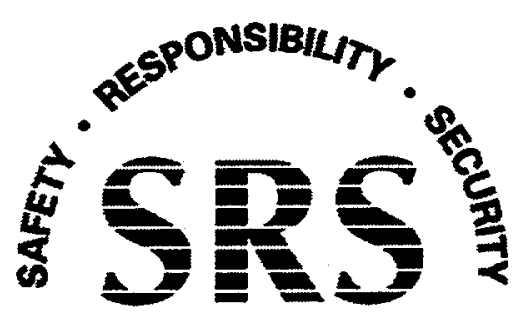

SAVANNAH RIVER SITE

Prepared for the U.S. Department of Energy under Contract No. DE-AC09-96SR18500 
DOCUMENT: WSRC-TR-98-0055

TITLE: $\quad$ APT BLANKET DETAILED BIN MODEL BASED ON

INITIAL PLATE-TYPE DESIGN - 3D FLOWTRAN-TF Model

\section{APPROVALS}

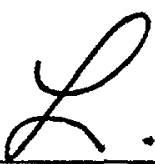

H. Ham

L. Larry Hamm, Task Leader (EM\&S Group/SRTC)

Date: $7-16-98$

\footnotetext{
L. Lary Hamm, Task Leader (EM\&S Group/SRTC)
}

Si Young Lee, Co-author (EM\&S Group/SRTC)

Date: $7-20-98$
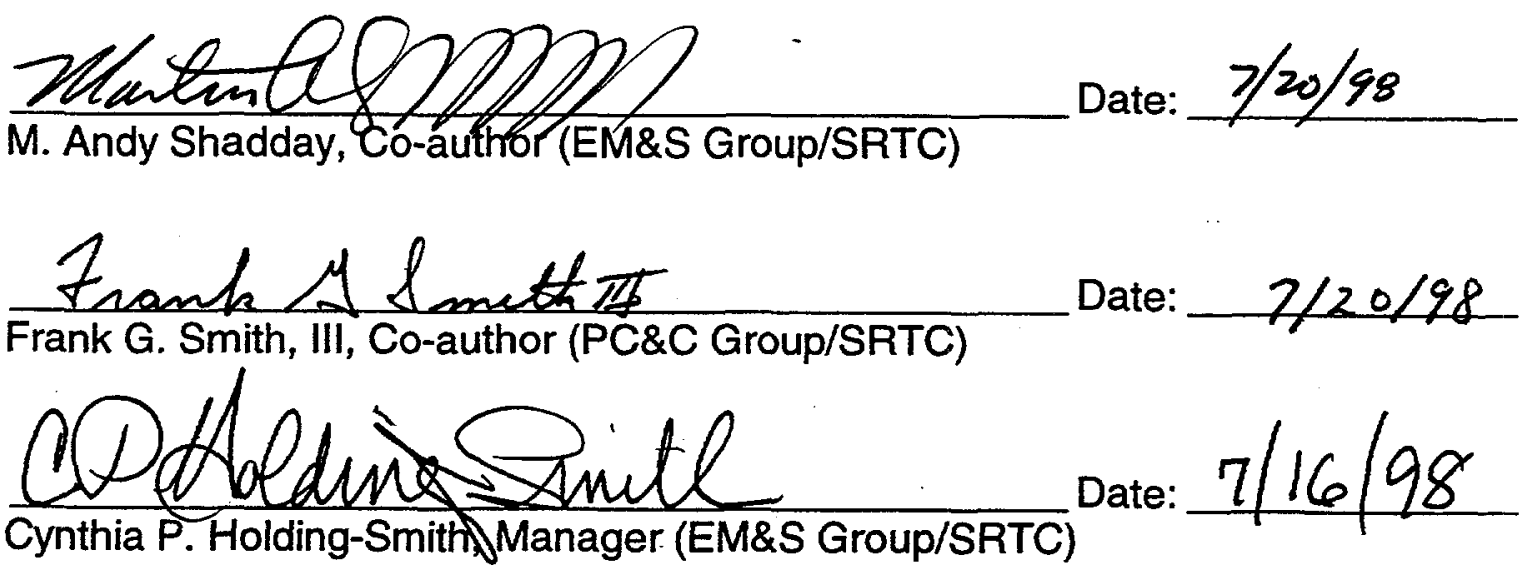

m.Q. E\&ra

Martha A. Ebra, Manager (EDS/SRTC)

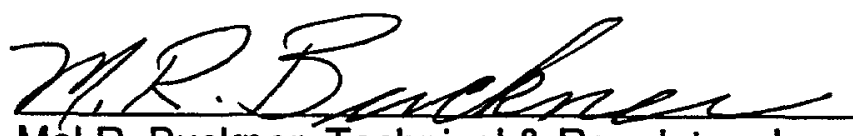

Mel R. Buckner, Technical \& Regulatory Lead (APT OPO)

Date: 28 ful 98

Date:

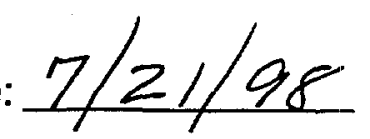

The internal technical review function is being performed at the APT project level and is coordinated through LANL. 


\section{Table of Contents}

1 Introduction

2 APT Blanket Model $\quad 2$

3 References $\quad 6$

Appendix A: Listing of Reference 1 Plate-Type Detailed Bin Model Input Deck

\section{List of Figures}

Figure 2-1 Finite element mesh of APT reference 1 blanket plate.

4

Figure 2-2 Three-dimensional mesh of APT reference 1 blanket plate.

\section{List of Tables}

Table 2-1 Flow Channel Parameters.

3 
(This Page Intentionally Left Blank) 


\section{Introduction}

This report provides background information for a series of reports documenting accident scenario simulations for the Accelerator Production of Tritium (APT) blanket heat removal systems [1-7]. The simulations were performed in support of the Preliminary Safety Analysis Report (PSAR) for the APT. This report gives a brief description of the FLOWTRAN-TF code which was used for detailed blanket bin modeling.

The FLOWTRAN-TF code was originally developed at the Savannah River Technology Center (SRTC) to solve transient conjugate heat transfer problems associated with single or two phase flow in reactor assemblies having multiple flow channels. In the reactors, as in the APT, the multiple flow channels are connected to common inlet and outlet plenums. FLOWTRAN-TF was specifically designed to model flow in this geometry. The code contains constitutive relations applicable to low pressure and low temperature two-component (air and water) flows in narrow channels. The original code contained fluid equations for two-dimensional flow in both the dominant axial direction and in the azimuthal direction to model flow across narrow rib gaps that were present in the reactor assemblies. FLOWTRAN-TF contains logic to map out the complete boiling curve with the following user options:

1. Diettus-Boelter or Sieder-Tate single phase heat transfer correlations.

2. Chen or Mikic-Rohsenow boiling heat transfer correlations.

3 Biasi, SRTC or Macbeth-Bowring critical heat flux correlations.

The original code was extensively documented [8-10], verified and validated [11] as part of the reactor restart effort at the Savannah River Site. The principal authors of the code are still active in code development work at the site and several members of the original development team were available to work on the APT analyses. Based on these considerations, the FLOWTRAN-TF code was chosen to provide detailed modeling of coolant flow and heat conduction for a single plate within the APT blanket modüle.

To simplify the code as much as possible for the APT application, the original twodimensional fluid flow equations were reduced to their one dimensional forms in a modified version of the FLOWTRAN-TF code. Several parameters in the original twodimensional formulation were specific for flow across the very narrow rib gaps in the reactor assembly flow channels. Therefore, reducing the code to one-dimensional fluid flow did not adversely impact the code capabilities for APT calculations.

The original FLOWTRAN-TF code was also designed specifically for three-dimensional heat conduction in a geometry of concentric cylindrical tubes which applied to the reactor assemblies. The solid heat conduction module in the code was replaced with two-dimensional implicit finite element calculations on an unstructured mesh capable of solving heat conduction problems in more general geometries and specifically in the blanket plate structures. An explicit axial heat conduction scheme using a finite difference formulation that couples adjacent axial levels allows the code to model threedimensional conjugate heat transfer within a blanket plate. 
At the level of detail required for the preliminary safety analysis, the heat conduction calculation imposes a significant computational burden on the model. Therefore, an effort was made to increase the computational efficiency of these calculations by using matrix reordering, efficient solution methods, and by adopting the simplification of assuming constant metal physical properties. For the range of temperatures experienced in the safety analysis calculations the assumption of constant metal properties is justified. Additionally, time steps for the fluid calculations are set by a Courant limit because of explicit differencing in the momentum equations. Under some flow conditions, the time step for the fluid calculations can become very small as the code attempts to converge to a solution within the specified tolerances. To avoid excessive computational times caused by performing the solid heat conduction calculations over these very small time intervals imposed by fluid convergence constraints, the time step for the conduction calculations is specified independently of that used by the fluid. That is, solid temperatures are updated at time steps independent of the time step used for the fluid calculations. While this approach may lead to some small error in the solid temperature, the significant increase in computational efficiency warrants its use. For further details on the modifications to FLOWTRAN-TF as discussed above, see Ref. [13].

\section{APT Blanket Model}

Figure 2-1 shows a cross-sectional view of the finite element mesh employed in the FLOWTRAN-TF heat conduction calculations. This mesh is based on the reference 1 blanket plate-type design for a lateral Row 1 component provided to SRTC by LANL personnel in mid October 1997 [12]. The FLOWTRAN-TF blanket model includes a single metal plate and the 12 associated half flow channels. Figure 2-1 shows the 12 half flow channels surrounding the plate and the numbering convention used for the channels. Seven of the channels are trapezoidal shaped slots and five of the channels are annuli between the plate and the helium tubes. Table 2-1 gives physical dimensions of the flow channels and the fraction of fluid in each channel under normal operating conditions. Twenty levels were used to discretize the plate model in the axial direction with 673 finite element nodes at each axial level. The mesh shown in Fig. 2-1 is used at each of the axial levels. Figure 2-2 shows the full three-dimensional mesh used for the solid heat conduction calculations. Based on preliminary design information, the reference 1 plate is approximately $0.1 \mathrm{~m}$ long, $0.025 \mathrm{~m}$ wide and $2.78 \mathrm{~m}$ high. In Figure $2-2$, scaling in the vertical direction is much smaller than that in the horizontal plane. Each flow channel forms a one-dimensional fluid cell and the axial discretization is the same in both the solid and the fluid. There are a total of 240 fluid cells in the entire plate model.

In all of the calculations, a 2 mil layer of aluminum oxide with a thermal conductivity of $2.16 \mathrm{~W} / \mathrm{m}-\mathrm{K}$ is assumed to be present on the outer surface of the plate. Also, a 1 mil air gap with a thermal conductivity of $0.10 \mathrm{~W} / \mathrm{m}-\mathrm{K}$ is assumed to be present between the aluminum cladding and the lead. The air gap represents a conservative model of the contact resistance between the two metal regions.

Calculations were performed to assess safety margins in the blanket design for loss of flow, loss of coolant and beyond design basis accident scenarios. Boundary conditions for the plate calculations specifying the total coolant flow, inlet temperature, outlet 
pressure, and inlet void fraction as functions of time are provided by a TRAC system model. Pressure at the inlet to the coolant channels is also input and is used to evaluate physical properties. The helium tubes were treated as adiabatic boundaries in the heat transfer calculations. In all of the calculations an adiabatic boundary condition was applied to the outer surface on the decoupler side of the mesh. For the LOCA [2-6] and LOFA [1] calculations, an adiabatic boundary condition was applied to the outer surface on the cavity side of the mesh as well. For the accident calculations with internally dry channels and a flooded cavity [7], the surface heat transfer coefficient on the cavity side of the plate was specified. These boundary conditions were specified through the code input and their implementation did not require any modifications to the code itself.

A sample input deck for the FLOWTRAN-TF code is provided in the Appendix. Annotations in the input deck explain some aspects of the code functionality.

Table 2-1 Flow Channel Parameters.

\begin{tabular}{|c|c|c|c|c|}
\hline $\begin{array}{l}\text { Channel } \\
\text { Number }\end{array}$ & $\begin{array}{c}\text { Fow Area } \\
\left(\mathrm{cm}^{2}\right)\end{array}$ & $\begin{array}{l}\text { Wetted } \\
\text { Perimeter } \\
\text { (cm) }\end{array}$ & $\begin{array}{c}\text { Hydraulic } \\
\text { Diameter } \\
(\mathbf{c m})\end{array}$ & Flow Split \\
\hline 1 & 0.4104 & 1.7862 & 0.9191 & 0.099 \\
\hline 2 & 0.3591 & 1.7298 & 0.8305 & 0.080 \\
\hline 3 & 0.2552 & 1.4618 & 0.6983 & 0.051 \\
\hline 4 & 0.1426 & 1.1247 & 0.8762 & 0.023 \\
\hline 5 & 0.9935 & 3.1412 & 0.1557 & 0.286 \\
\hline 6 & 0.3064 & 1.5919 & 0.5616 & 0.065 \\
\hline 7 & 0.4398 & 2.6141 & 0.8301 & 0.086 \\
\hline $8-12$ & 0.4598 & 4.8277 & 0.3810 & 0.062 \\
\hline
\end{tabular}




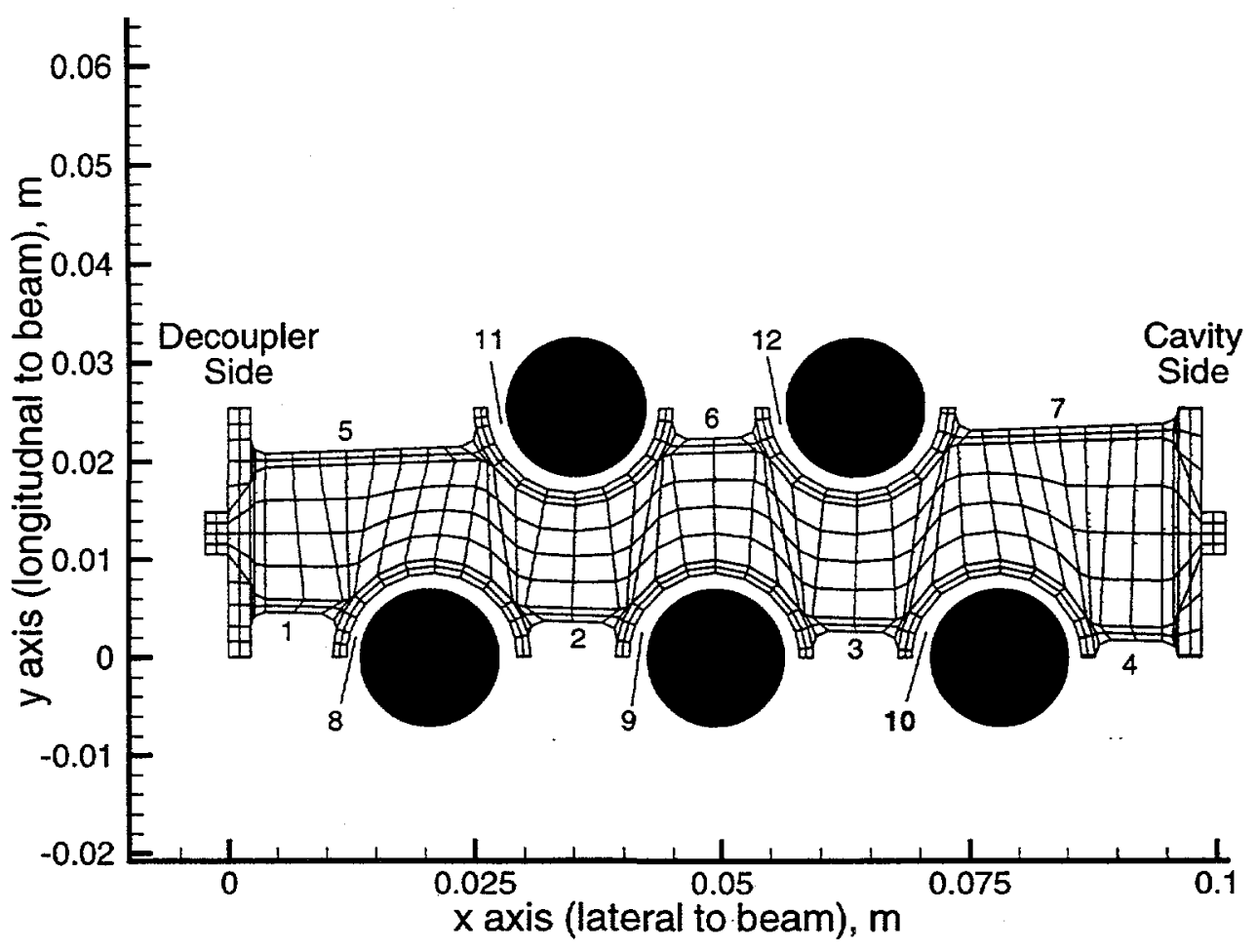

Figure 2-1 Finite element mesh of APT reference 1 blanket plate. 


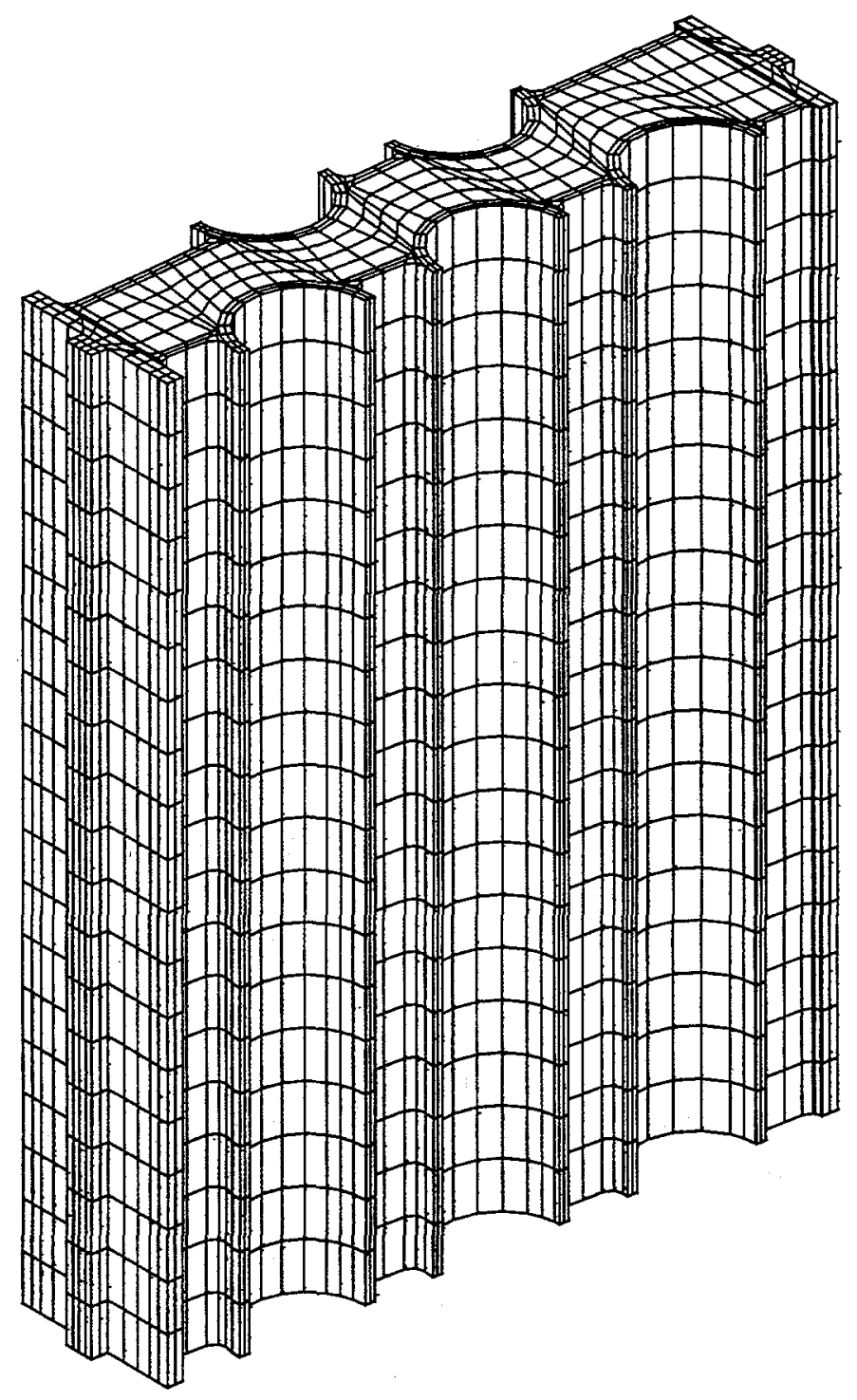

Figure 2-2 Three-dimensional mesh of APT reference 1 blanket plate. 


\section{References}

1. L. L. Hamm, S. Y. Lee, M. A. Shadday, and F. G. Smith, III, "APT Blanket System Loss-of-Flow Accident (LOFA) Analyses Based on Initial Conceptual Design Case 1: with Beam Shutdown and Active RHR," Westinghouse Savannah River Company, WSRC-TR-98-0058 (July 1998).

2. L. L. Hamm, S. Y. Lee, M. A. Shadday, and F. G. Smith, III, "APT Blanket System Loss-of-Coolant Accident (LOCA) Analysis Based on Initial Conceptual Design Case 1: External HR Break Near Inlet Header," Westinghouse Savannah River Company, WSRC-TR-98-0059 (July 1998).

3. L. L. Hamm, S. Y. Lee, M. A. Shadday, and F. G. Smith, III, "APT Blanket System Loss-of-Coolant Accident (LOCA) Analysis Based on Initial Conceptual Design Case 2: External HR Break at Pump Outlet with Pump Trip," Westinghouse Savannah River Company, WSRC-TR-98-0060 (July 1998).

4. L. L. Hamm, S. Y. Lee, M. A. Shadday, and F. G. Smith, III, "APT Blanket System Loss-of-Coolant Accident (LOCA) Analysis Based on Initial Conceptual Design Case 3: External HR Break at Pump Outlet without Pump Trip," Westinghouse Savannah River Company, WSRC-TR-98-0061 (July 1998).

5. L. L. Hamm, S. Y. Lee, M. A. Shadday, and F. G. Smith, III, "APT Blanket System Loss-of-Coolant Accident (LOCA) Analysis Based on Initial Conceptual Design Case 4: External Pressurizer Surge Line Break Near Inlet Header," Westinghouse Savannah River Company, WSRC-TR-98-0062 (July 1998).

6. L. L. Hamm, S. Y. Lee, M. A. Shadday, and F. G. Smith, III, "APT Blanket System Loss-of-Coolant Accident (LOCA) Analysis Based on Initial Conceptual Design Case 5: External RHR Break Near Inlet Header," Westinghouse Savannah River Company, WSRC-TR-98-0063 (July 1998).

7. L. L. Hamm, S. Y. Lee, M. A. Shadday, and F. G. Smith, III, "APT Blanket System Internally Dry Flooded Cavity Accident (IDFCA) Based on Initial Plate-Type Design - Demonstration of Bin Heat Conduction Capability," Westinghouse Savannah River Company, WSRC-TR-98-0064 (July 1998).

8. Aleman, S. E., G. P. Flach, L. L. Hamm, S. Y. Lee and F. G. Smith, III, "FLOWTRAN-TF Software Design," Westinghouse Savannah River Company, WSRC-TR-92-532, (February, 1993).

9. Aleman, S. E., R. E. Cooper, G. P. Flach, L. L. Hamm, S. Y. Lee and F. G. Smith, III, "FLOWTRAN-TF v1.2 Source Code," Westinghouse Savannah River Company, WSRC-TR-93-086 (February, 1993).

10. Flach, G. P., S. Y. Lee and S. E. Aleman, "FLOWTRAN-TF User Guide," Westinghouse Savannah River Company, WSRC-TR-93-085, (February, 1993).

11. Aleman, S. E., G. P. Flach, J. W. Jerrell, S. Y. Lee, M. A. Shaddy and F. G. Smith, III, "FLOWTRAN-TF Software Testing," Westinghouse Savannah River Company, WSRC-TR-93-084, (February, 1993).

12. R. Kapernick, "Blanket Reference 1 Plate-Type Design for Lateral Row 1 Module", e-mail memo from Los Alamos National Laboratory, Oct. 11, 1997.

13. L. L. Hamm, S. Y. Lee, M. A. Shadday, and F. G. Smith, III, "FLOWTRAN-TF Code Modifications made for APT Blanket Safety Analyses", Westinghouse Savannah River Company, WSRC-TR-98-0056 (July 1998). 